\title{
ЕТАПИ ДІЯЛЬНОСТІ Й РЕПЕРТУАРНА ЛІНІЯ ПОЛТАВСЬКОГО ОПЕРНОГО ТЕАТРУ 20-Х РОКІВ ХХ СТОЛІТТЯ (ДЖЕРЕЛОЗНАВЧИЙ АСПЕКТ)
}

Андрсєва B. I.

\section{ВСТУП}

Організація в Полтаві оперної трупи припала на складний політичний та економічний період, становлення в Україні більшовицької влади. Його діяльність не завжди мала стабільний і рівний характер, тому іiі умовно можна розділити на три етапи:

- організаційний етап, коли в місті були здійснені перші спроби створення оперного колективу та перший сезон його роботи;

- етап стабільної діяльності, коли колектив мав більш-менш сталий склад солістів і здійснив основні постановки свого репертуару;

- завершальний етап, коли для продовження роботи колективу дирекція вимушена була залучити до виконання провідних партій цілий ансамбль солістів Харківського оперного театру та здійснила останню спробу створити власну трупу.

У 20-х роках XX ст. музично-театральна Полтава мала всі складники для організації в місті повноцінного оперного театру. Високопрофесійний симфонічний оркестр ще в кінці XIX століття заснований видатним полтавським митцем, віртуозом-скрипалем, диригентом Дмитром Ахшарумовим. Достатня кількість українських, співаючих акторів і російських оперних співаків опинилася в Полтаві через революційні події 1917 року. Активно працювало Полтавське музичне училище, яке щорічно випускало професійних вокалістів, хористів та оркестрантів. Для проведення оперних вистав у місті було спеціально облаштоване приміщення Міського театру 3 прекрасною акустикою. Полтавська публіка була добре знайома $з$ оперним мистецтвом завдяки активній у той час гастрольній діяльності пересувних італійських і російських оперних труп.

\section{1. Художнс керівництво та склад солістів}

\section{Полтавського оперного театру}

Фундатором і художнім керівником Полтавського оперного театру став диригент Олександр Єрофєєв. Закінчивши Московську консерваторію по класу тромбона, митець деякий час працював в оркестрах Казанської та Харківської опер. У 1912 році Д. Ахшарумов запросив його до Полтави як оркестранта в Полтавський симфонічний 
оркестр і викладача в музичне училище, де продовж 1912-1932 років О. Срофєєв викладав теорію музики, гармонію, поліфонію та оркестровий клас. Після від'їзду в кінці 1918 року з Полтави Д. Ахшарумова він перебрав на себе ще й обов'язки по керівництву Полтавським музичним училищем (пізніше технікумом) і симфонічним оркестром. У Полтавському оперному колективі працював продовж усього його існування (1919-1926 pр.) Пізніше став диригентом Вінницької та Лівобережної пересувних опер, Донецької опери в Луганську й Горькому театрі опери та балету ${ }^{1}$.

3 Полтавою пов'язаний початок творчої діяльності й відомого пізніше білоруського митця Іллі Гітгарця. Закінчивши Петербурзьку консерваторію, він у 1919 році приїхав до Полтави, де спочатку працював концертмейстером партії скрипок у Полтавському симфонічному оркестрі, а пізніше став другим диригентом оперного колективу ${ }^{2}$. У 1922 році митець залишив Полтаву. Працював у багатьох російських оперних колективах, а також став одним із організаторів і диригентів Білоруської оперної студії й Білоруського театру опери та балету. У Полтаві відбулося творче зростання й майбутнього видатного хорового диригента, багаторічного ректора Московської консерваторії Олександра Свєшникова. У 1921-1923 роках він керував у Полтаві оперним хором і місцевою хоровою капелою. Режисуру в Полтавському оперному колективі в різні роки здійснювали С. Коробов, М. Муравйов, Е. Юнгвальд-Хількевич, А. Кононович.

Склад солістів оперної трупи формувалася зі співаків, які з різних причин опинялися в Полтаві або спеціально були запрошені до колективу. Однією з фундаторів Полтавського оперного театру стала колишня примадонна театру М. Садовського, акторка-співачка української музично-драматичної трупи Василина Старостинецька. Співачка залишила помітний слід в історії музично-театрального життя Полтави, адже без іiі участі не проходила жодна знакова подія в місті. Очевидиця тих подій О. Чернова в спогадах так описує іiі: «Серед сопрано на першому плані, звичайно, була Старостинецька Василина Трифонівна, володарка драматичного сопрано. <..> Голос у неї був феноменальний, могутнього звучання, широкого діапазону» ${ }^{3}$. На жаль, у 1928 році В. Старостинецька разом зі своїм чоловіком О. Срофєєвим назавжди покинула Полтаву. Пізніше виступала в складі Вінницької та Лівобережної опер, була солісткою Донецького й Горьківського оперних театрів.

\footnotetext{
${ }^{1}$ Срофєєв О. Автобіографія. Музей «Музична Полтавщуина» Полтавського музичного коледжу імені М.В. Лисенка. Інв. № 7/4. Арк. 4.

${ }^{2}$ Єрофєєв О. Лист до К. Данилової від 19.03.1963. Музей «Музична Полтавщчина». Інв. № 333/21. Арк. 5-6.

${ }^{3}$ Чєрнова О. Полтавська опера 1920-1925 років. (Спогади очевидця). Лисенко I. Музична культура України у спогадах, матеріалах, листах. Київ : Рада, 2008. С. 108.
} 
Біля витоків Полтавського оперного театру також стояв відомий співак, володар унікального голосу Іван Козловський. Ще будучи студентом 2-го курсу Київської консерваторії, він був запрошений до щойно організованої в Полтаві української музично-драматичної трупи для виконання тенорових партій у музичних виставах. Гастролі I. Козловського мали тривати всього два місяці, після чого він повинен був повернутися назад на навчання в Київ, однак чергова зміна влади в Україні надовго затримала співака в Полтаві. І. Козловський стає активним учасником усіх спроб організації в Полтаві оперної трупи. У кінці 1920 року він вступає до лав Червоної Армії, проте завдяки прихильному до нього ставленню начальства продовжує виступи у виставах оперного театру. Після закінчення служби в армії співак залишився в Полтаві ще на деякий час, працював інспектором народної освіти, а в сезонах 1922-1924 років був офіційним солістом Полтавського оперного театру. На початку 1924 року він переходить на роботу до Харківської опери. Пізніше виданий український співак працював у Свердловському оперному театрі й упродовж майже тридцяти років був окрасою Большого театру в Москві. Активну участь в організації оперної трупи в Полтаві також брали професійні російські оперні співаки Йосип Милославський, що відзначався «надзвичайно красивим і потужним голосом широкого діапазону» ${ }^{4}, \mathrm{i}$ його дружина Лідія Днєпрова. Подружжя працювало в Полтаві недовго й уже в кінці сезону 1921-1922 років назавжди покинуло місто.

Першим виконавцем баритонових партій у Полтавському оперному театрі був російський співак Михайло Зубов, який прибув у Полтаву 3 Тифлісу. «Це був могутній драматичний баритон, надзвичайно артистичний i музикальний співак» ${ }^{5}$, що володів «достатньою різнобарвністю тембрів і м'якістю фразування» ${ }^{6}$. Поряд із М. Зубовим баритонові партії виконував місцевий співак К. Торвік-Гарло. У сезоні 1922-1923 років партії драматичного баритона виконував А. Уфимський, після чого перейшов на роботу до Харківської державної опери. Його місце зайняв запрошений соліст з Одеської опери Григорій Генарі, який у кінці сезону 1923-1924 років також залишив Полтаву і став солістом Ленінградського оперного театру. У грудні 1923 року для виконання баритонових партій у Полтаву запросили соліста Київського оперного театру К. Суслова, який уже після свого першого виступу завоював симпатії полтавських глядачів. «Чувство меры в игре, выигрышные сценические данные, четкая фразировка при среднем, но достаточно разработанном голосе - все это выгодно выделяет его» ${ }^{7}$

\footnotetext{
${ }^{4}$ Алеко. «Вертер». Вісти (Известия). 1921. № 96 (271). 13 мая. С. 2.

5 Чернова О. Згадувана праця. С. 110.

${ }^{6}$ Алеко. 3-й симфонический концерт. Вісти (Известия). 1921. № 14 (189). 22 января. С. 3.

${ }^{7}$ Г. Ш. «Евгений Онегин. Голос труда. 1923. № 285 (1026). 14 декабря. С. 4.
} 
Найбільш яскравим i професійним виконавцем басових партій у Полтавському оперному театрі був Іван Плешаков. У Полтаву співак прибув восени 1921 року з Ростовської опери. Полтавська преса одразу помітила, що завдяки красивому широкому голосу та яскравим артистичним даним його, безсумнівно, чекає блискуча вокальна кар'єра ${ }^{8}$. Співак працював у Полтаві два сезони й у 1923 році перейшов на роботу до Ленінградського оперного театру. На місце I. Плешакова був запрошений Д. Раєв. Найактивнішим i найбільш відданим Полтавському театру в басовій групі був Василь Полив'яний. «Він був 3 місцевих полтавців, - стверджувала О. Чернова, - мав педагогічну освіту. Співу, очевидно, навчався самотужки» ${ }^{9}$. У виставах співак виконував як провідні, так і другорядні партії.

Однією 3 перших солісток оперної трупи стала уродженка міста Полтави Римма Фішер. Після навчання в Санкт-Петербурзькій консерваторії по класу фортепіано повернулася до Полтави. У сезоні 1921-1922 років вступила до оперної трупи Полтавської опери, де виконувала майже всі головні та другорядні оперні партії для ліричного сопрано. У кінці сезону 1922-1923 років співачка перейшла на роботу в Харківську оперу. Пізніше працювала в Київському оперному театрі, 3 яким під час Другої світової війни евакуювалася до Уфи, де залишилася працювати викладачем по вокалу в Башкирському державному театрі опери та балету й в Уфимському училищі мистецтв ${ }^{10}$. Серед виконавиць жіночих партій також виділялася ліричне сопрано Єлизавета Арсеньєва, що в сезоні 1922-1923 років перейшла на роботу в Полтаву 3 Ростовської опери. Преса відзначала, що «у артистки небольшой, несколько тусклый голос, но артистка умеет им владеть. Играет и поет Арсеньева просто без каких-либо карикатурных «ужастей», на которых мы насмотрелись у наших сопрано» ${ }^{11}$. За твердженням О. Чернової, Є. Арсеньєва була улюбленою партнеркою I. Козловського ${ }^{12}$. Працювала в Полтаві до кінця сезону 1923-1924 років. На жаль, співачка передчасно померла. У 1922-1923 роках у Полтаві також працювали драматичні сопрано Ф. Образцовська й запрошена солістка Одеського оперного театру Н. Бартош-Седенко.

Яскраву сторінку в історію Полтавського оперного театру вписала Олександра Ропська (мецо-сопрано), яка приїхала в Полтаву в 1919 році після закінчення Саратовської консерваторії, де навчалася по класу фортепіано. Виступала спочатку в виставах української музичнодраматичної трупи, паралельно брала уроки вокалу у видатної

\footnotetext{
${ }^{8}$ Внук. «Полярная звезда». Открытие сезона. Голос труда. 1922. № 80 (602). 9 июля. С. 4.

${ }^{9}$ Чернова О. Згадувана праця. С. 110.

10 Башкирская энциклопедия / гл. ред. М.А. Ильгамов. Уфа, 2011. Т. 7. Ф-Я. С. 624.

${ }_{11}$ Алеко. «Паяцы» Леонкавалло. Вісти (Известия). 1921. № 275 (445). 16 декабря. С. 2.

12 Чернова О. Указана праця. С. 109.
} 
полтавської викладачки М. Денисенко ${ }^{13}$. Упродовж двох сезонів 1922-1924 років виконала близько п’ятнадцяти мецо-сопранових партій. У 1924 році прийняла запрошення відомого співака Енріко Гафта працювати в керованій ним пересувній оперній трупі й залишила Полтаву. Пізніше була солісткою Одеського, Харківського й Київського театрів опери та балету. Поряд із О. Ропською мецо-сопранові партії у виставах Полтавського оперного театру виконували Павлова та Ф. Ровинська, а також артистка української музично-драматичної трупи М. Костюченко.

Найбільш плинною серед солістів Полтавського оперного колективу була група тенорів. Окрім I. Козловського та Й. Милославського, виконавцем тенорових партії на початковому етапі роботи театру був російський співак Я. Завалов. Він володів звучним драматичним тенором красивого тембру однак, міг виконувати як драматичний, так і ліричний репертуар ${ }^{14}$. Пізніше тенорові партії виконували також I. Лопатін, артисти київських театрів Р. Смельянов і В. Ісаков, запрошені солісти Одеської опери Я. Владіміров та М. Зложинський.

\section{2. Гастролі відомих оперних співаків на сцені Полтавського оперного театру}

Склад солістів Полтавського оперного колективу постійно змінювалася. Отримавши більш вигідні пропозиції, співаки могли залишити Полтаву в будь-який час, навіть посередині сезону. Тому до участі у виставах Полтавського колективу часто запрошували солістів інших оперних театрів. Багатим на гастрольні виступи був літній сезон 1922 року. Тоді до Полтави завітали відомі співаки: В. Брюно, А. Лебедєва, П. Карпова (сопрано), В. Товстолужська (мецо-сопрано), А. Каченовський (бас), А. Лабицький (тенор). А в травні 1924 року у виставах Полтавського оперного колективу взяв участь одразу цілий ансамбль солістів Державної Харківської опери: П. Карпова, Е. Зелінська, В. Ухов, М. Синицький та М. Рейзен. Вони виступили в операх «Аида» Дж. Верді, «Тоска» Дж. Пучіні, «Евгений Онегин» та «Пікова дама» П. Чайковського ${ }^{15}$. Критика дуже високо оцінила гастролерів: «Редко приходилось полтавчанам слушать и видеть «Аиду» в таком исключительном по достоинствам исполнения состава первых ролей. Особенно выделялись. Карпова (Аида), Зелинская (Амнерис), Рейзен (Рамфис) и Ухов (Амонасро) ${ }^{16}$.

Яскравою подією полтавського музично-театрального життя були гастролі відомих співаків П. Цесевича, М. Бочарова та Г. Пирогова.

\footnotetext{
13 Донцов В.П. А голос так дивно звучал. Киев: Альфа Реклама, 2010. С. 247.

14 Алеко. Оперный вечер. Вісти Известия. 1920. № 119. 24 октября. С. 3.

15 Оперные гастроли. Голос труда. 1924. № 102 (1146). 6 мая. С. 4.

${ }^{16}$ Г. Ш. Открытие оперных гастролей. Голос труда. 1924. № 110 (1154). 15 мая. С. 3.
} 
Першим у виставах Полтавського оперного театру виступив Платон Цесевич у березні 1922 року. Він узяв участь в операх «Русалка» О. Даргомижського, «Севільський цирульник» Дж. Россіні та «Фауст» Ш. Гуно. Про виконання однієї з його коронних партій Мельника преса писала: «С первой минуты уже костюмом он создает впечатление. У артиста богатейшая игра, поэтому его Мельник на сцене одухотворенная личность. Голос Цесевича, выдвинувший его чуть ли на второе место после Шаляпина местами звучал широко и свободно, передавая мельчайшие нюансы. Цесевич пользовался успехом, как артист, лучше которого Полтаве за последние годы видеть не приходилось» ${ }^{17}$. Відомо також про участь П. Цесевича в «Запорожці за Дунаєм» С. ГулакаАртемовського, де він виконав партію Карася. Поряд із ним головні партії також співали В. Старостинецька (Одарка), I. Козловський (Андрій), Р. Фішер (Оксана) та М. Зубов (Султан) ${ }^{18}$. Наступного разу П. Цесевич завітав до Полтави в січні 1924 року. У його виконанні прозвучали басові партії в операх «Фауст» Ш. Гуно, «Севільський цирульник» Дж. Россіні, «Пікова дама» П. Чайковського та «Борис Годунов» М. Мусоргського. В останній опері він виконав одразу дві ролі - Бориса та Варлаама ${ }^{19}$.

Відомий російський оперний співак, артист Московської опери С. Зиміна та Ленінградського оперного театру Михайло Бочаров гастролював в Полтаві влітку 1924 року. Разом із колишнім вихованцем Полтавського оперного колективу, а на той час уже солістом Ленінградського оперного театру I. Плешаковим він узяв участь у виставах «Фауст» Ш. Гуно, «Севільський цирульник» Дж. Россіні, «Ріголетто» $\mathrm{i}$ «Травіата» Дж. Верді.

Володар феноменальних вокальних даних, соліст Маріїнського та Большого оперних театрів, Григорій Пирогов завітав до Полтави на початку 1926 року для участі у виставах «Фауст» Ш. Гуно й «Борис Годунов» М. Мусоргського. Із цього приводу преса писала: «Виступ баса Пирогова був справжньою насолодою для тих, хто особливо цінує в співах надзвичайну виразність передачі, художнє вміння оживити пісню чи арію, насичити іiі всіма відтінками героїчного підвищення або густого гумору. Правда, голос співця трохи «здав» уже в силі, в мощі звуку. Але тонкості вокального мистецтва, що ним цілком володіє артист, радують слухача самі по собі» ${ }^{20}$.

\footnotetext{
${ }^{17}$ Алеко. Гастроль Цесевича и Карасуловой. Вісти (Известия). 1922. № 65 (515). 23 марта. С. 4.

${ }^{18}$ Афіша опери «Запорожець за Дунаєм» С. Гулака-Артемовського. Музей «Музична Полтавщина». Інв. № 169.

${ }^{19}$ Г. Ш. Гастроли Цесевича. «Борис Годунов» Мусоргского. Голос труда. 1924. № 29 (1073). 5 февраля. С. 5.

${ }^{20}$ Г. Ш. Концерт Пирогова. Робітник. 1926. № 5 (54). 8 січня. С. 4.
} 


\section{3. Організаційний етап діяльності Полтавського оперного театру (1919-перша половина 1921 років)}

Уперше питання про організацію в Полтаві оперної трупи виникає весною 1919 року $^{21}$. Об'єднавши свої зусилля, диригент Полтавського симфонічного оркестру О. Єрофєєв та актори-співаки української музично-драматичної трупи на чолі $3 \mathrm{~B}$. Старостинецькою вирішили здійснити постановку «Євгенія Онєгіна» П. Чайковського. Після довгої підготовки 3 червня 1919 року відбулася прем'єра опери, яка, за спогадами О. Срофєєва, пройшла 3 великим художнім успіхом i показала, що «при условии затраты достаточного количества труда и энергии, а главное при наличии любви к искусству, является вполне возможным осуществить в Полтаве постоянное оперное дело» ${ }^{22}$. На жаль, із приходом у липні 1919 року в місто армії Денікіна вистави оперної трупи припинилися ${ }^{23}$.

У лютому 1920 року, після стабілізації політичної ситуації в Україні, здійснена друга спроба утворити в Полтаві тепер уже Українську оперу $^{24}$. Ініціатором створення колективу стала колишня примадонна українського театру М. Садовського В. Старостинецька ${ }^{25}$. Окрім неї, у склад солістів ще входили М. Левицька (ліричне сопрано), M. Костюченко (мецо-сопрано), I. Козловський (ліричний тенор), Севологорський (баритон), В. Полив'яний (бас) ${ }^{26}$. Першою поставкою стала опера М. Лисенка «Утоплена», головні партії в якій виконували В. Старостинецька (Панночка) та І. Козловський (Левко). Однак, як згадує О. Єрофєєв, і ця спроба виявилася невдалою: «... найдя содержание оперы в материальном отношении непосильной для Губнаробраза, последний ликвидировал это предприятие после двух постановок» ${ }^{27}$.

Трохи пізніше, у серпні 1920 року, у місті був створений новий оперний колектив - Російська опера під керівництвом Й. Милославського ${ }^{28}$. Як свідчать оголошення в газеті, склад солістів становили переважно російські співаки Л. Дніпрова, Б. Заславська, М. Зубов та інші, які через несприятливі політичні умови опинилися на той час у Полтаві. Оркестром керував молодий перспективний диригент I. Гітгарц. Новостворений колектив упродовж серпня-грудня 1920 року здійснив постанови таких складних опер, як «Кармен» Ж. Бізе, «Аїда» Дж. Верді, «Трубадур» Дж. Верді, а також «Севільський цирульник» Дж. Россіні. Однак значні купюри в операх, недостатньо

\footnotetext{
${ }^{21}$ Известия. 1919. № 68 (84). 11 мая.

22 Єрофєєв О. Автобіографія. Арк. 4.

23 Там само.

24 Для Української Опери. Радянська влада. 1920. Ч. 58 (73). 10 березня. С. 3.

25 Довідка Старостинецькій. Музей «Музична Полтавщина». Інв. № 5/3.

26 Украинская опера Музкома. Радянська влада. 1920. Ч. 53 (68). 4 березня. С. 2.

${ }^{27}$ Єрофєєв О. Автобіографія. Арк. 5.

${ }^{28}$ Оперная труппа. Вісти (Известия). 1920. № 92. 19 сентября. С. 3.
} 
укомплектований хор та оркестр, заміна речитативів прозою, невідповідність голосових даних співаків виконуваним ними партій, тіснота приміщення піхотних Командних курсів, у яких відбувалися вистави, несприятливо відобразилися на якості нових постановок. Вони нещадно критикувалися пресою й через деякий час i цей колектив припинив свою діяльність ${ }^{29}$.

Однак полтавські митці не залишали надії на створення в місті оперної трупи. Тому вже у квітні 1921 року, об'єднавши всі вокальні сили в місті, нарешті створили стаціонарний колектив - Полтавський оперний театр. «Серьёзная постановка дела, - писала місцева преса, позволяет нам надеяться, что опера станет на твердые ноги. Если же Политаросвет обратит должное внимание на оперу, то надежда претворится в действительность. Во всяком случае, Полтава сделала новое культурное приобретение, ценность которого для всех ясна. Нужно приложить все усилия, чтобы развить это дело и создать в Полтаве постоянную оперу, на которую Полтава, как одна из крупнейших центров Украины, имеет полное право» ${ }^{30}$. При оперному хорі була організована студія, у якій викладав сольфеджіо й елементарну теорію музики О. Свєшников ${ }^{31}$, режисуру здійснював С. Коробов.

Новостворений колектив розпочав свою роботу з постановки опери «Євгеній Онєгін» П. Чайковського під диригуванням О. Срофєєва. Головні партії виконували декілька складів виконавців: Онєгін М. Зубов, К. Торвік-Гарло; Тетяна - В. Старостинецька, Чернявська; Лєнський - Я. Завялов, І. Козловський; Ольга - Л. Дніпрова, М. Костюченко; Няня - Коваленко. Зауважимо, що майбутня зірка Большого театру в Москві І. Козловський виконував у цій постановці спочатку партію Тріке й лише в четвертому складі - Ленського. Однак це не завадило йому одразу ж завоювати симпатії глядачів і рецензентів: «Очень благоприятное впечатление оставил И. Козловский в роли Ленского. У артиста небольшой, но удивительно красивый тенор, кроме того Козловский обладает хорошей драматической игрой, чего лишено большинство оперных артистов» ${ }^{32}$.

Уже через місяць, у травні 1921 року, полтавській публіці була представлена нова опера «Вертер» Ж. Массне. Однак, судячи з відгуків преси, вона була не зовсім вдалою: «Оперное дело может существовать несколько лет и ни разу не поставить «Вертер». Это не репертуарная опера и ставится главным образом для гастролеров, потому, что роль Вертера представляет громадные требования исполнителю. Для того, чтобы сыграть Вертера нужен мягкий, лирический тенор и богатая

\footnotetext{
${ }^{29}$ Алеко. Оперные спектакли. Вісти (Известия). 1920. № 146. 26 ноября. С. 2

30 Алеко. «Евгений Онегин». Вісти (Известия). 1921. № 83 (258). 23 апреля. С. 2.

${ }_{31}^{31}$ Студия при оперном хоре. Вісти (Известия). 1921. № 29 (204). 11 февраля. С. 4

32 Алеко. «Евгений Онегин». Вісти (Известия). 1921. № 107 (282). 26 мая. С. 2.
} 
драматическая игра. Наш полтавский «гастролер» Милославский, не имеет ни того, ни другого. <..> У дирижерского пульта - И. Гітгарц. Молодой, многообещающий дирижер иногда забывает, что перед ним не симфонический оркестр и заглушает певцов, которые и без того особенной силой голосовых данных не отличаются» ${ }^{33}$.

Не залишаючи думки про виконання в Полтавському оперному театрі україномовних творів, В. Старостинецька стає ініціаторкою постановки опери «Галька» С. Монюшка українською мовою. I хоча спочатку ця опера виконувалася російською мовою, уже 24 липня 1921 року відбулася прем'єра опери в українському перекладі, яку здійснив полтавський культурно-просвітницький діяч В. Щепотьєв ${ }^{34}$. Головні партії українською мовою виконували: Галька - В. Старостинецька, Йонтек - І. Козловський, Януш - К. Торвік-Гарло, Софія - М. Костюченко. Завершався перший сезон постановкою опери Ж. Бізе «Кармен» під диригуванням І. Гітгарця. Головні партії виконували: Кармен Л. Дніпрова, В. Старостинецька, М. Костюченко, Хозе - Й. Милославський і Зав'ялов, Ескамільо - М. Зубов, Мікаела - Чернявська, Фраскіта - Р. Фішер, Марседес - Коваленко. Маючи в своєму репертуарі впродовж першого сезону лише чотири опери, Полтавський оперний театр, тим не менше, розгорнув активну діяльність, виконуючи вистави майже щодня ${ }^{35}$.

\section{4. Етап стабільної діяльності Полтавського оперного театру (сезони 1921-1924 років)}

На початку сезону 1921-1922 рр. трупу солістів полтавської оперної трупи поповнили колишні солісти Ростовської державної опери: Є. Арсеньєва (ліричне сопрано), Львов (тенор), Альянов (баритон) та I. Плешаков (бас-кантанте) ${ }^{36} .3$ урахуванням творчих можливостей цих співаків у новому сезоні було здійснено п'ять нових постановок: «Русалка» О. Даргомижського, «Травіата» Дж. Верді, «Демон» А. Рубінштейна, «Фауст» Ш. Гуно, «Паяци» Р. Леонкавалло.

Наприкінці 1921 року, у зв'язку з переходом у країні на нову економічну політику (НЕП), правління союзу «Рабіс» разом із Губполітпросвітою Полтави вирішили залишити державне фінансування лише трьом драматичним трупам Полтави (українській, російській, єврейській) і симфонічному оркестру. Усі інші колективи, включаючи Полтавський оперний театр, мали перейти на самозабезпечення ${ }^{37}$. Таке рішення найбільш тяжко відобразилося на роботі оперного колективу, що й так важко окупався. Скрутне матеріальне становище змусило

\footnotetext{
${ }_{33}$ Алеко. «Вертер». Вісти (Известия). 1921. № 96 (271). 13 мая. С. 2.

${ }^{34}$ В театрах. Вісти (Известия). 1921. № 152 (322). 22 июля. С. 2.

35 Репертуар 1-го Советского театра. Вісти (Известия). 1921 г. № 154 (324). 24 июля. С. 3.

${ }^{36}$ Большой вокальный концерт. Вісти (Известия). 1921. № 253 (423). 20 ноября. С. 2

${ }^{37}$ Передача театров в руки коллективов. Вісти (Известия). 1921. № 274 (444). 15 декабря. С. 2.
} 
керівництво Полтавського оперного театру в подальшому виборі репертуару орієнтуватися на смаки так званої «непманівської» публіки, яка хотіла бачити на сцені більше розважального репертуару, унаслідок чого літній сезон 1921-1922 років відзначився постановками трьох оперет: «Корневільських двонів» Р. Планкета, «Сільви» І. Кальмана та «Гейші» С. Джонса.

На нові постановки одразу негативно відреагувала критика. Розуміючи, що тогочасній публіці часто подобалася балаганщина та групові трюки, преса закликала полтавський колектив не забувати про виховну функцію театру ${ }^{38}$. Про прем'єру «Сільви» І. Кальмана писалося: «Не имея собственных сил и возможностей пополнить свой репертуар серьезными постановками, А. Г. Ерофеев пошел на компромисс, и на его дирижерском пульте появилась оркестровка «классической оперетты» «Сильвы». Все это сильно исказило физиономию нашего оперного дела» ${ }^{39}$. «Нельзя сказать, чтобы трудооперный коллектив не потрудился над постановкой «Сильвы», но дело свое он не довел до конца и, что называется, поспешил скоро собрать сбор. В каждом штрихе чувствовалась незаконченность. «Сильвы» не было ${ }^{40}$. Критикувалася також нездібність оперних артистів приноровитися до нового жанру, особливо до розмовних (речитативних) діалогів ${ }^{41}$. Уважаючи театр одним із знарядь класової боротьби та провідником нових починань сутності суспільного буття, преса наполягала на тому, що керівником театру може бути тільки держава. «Предпринимательская инициатива, обычно просто и быстро разрешает подобные задачи. Искусство и особенно театр рассматриваются ею, как источник дохода. Идейные цели предпринимательству органически чужды. <...>. И поэтому верить театры частной инициативе так же опасно, как осуществить пресловутую «свободу» печати для врагов рабоче-крестьянского государства ${ }^{42}$. Імовірно, тому на початку сезону $1922-1923$ років у газеті «Голос труда» було оголошено: «Губно постановило ликвидировать оперу как коллектив не дающий никакого полит-художественного воспитания» ${ }^{43}$. Однак уже через місяць було анонсовано початок нового зимового сезону, який порадував полтавську публіку новими постановками. Збільшився й склад солістів: Ф. Образцовська (драматичне сопрано), Є. Арсєньєва, Р. Фішер (ліричне сопрано), Павлова, Ф. Ровинська, О. Ропська (мецо-сопрано), I. Козловський, І. Лопатін, Александров (тенори), М. Авраменко, Романов, А. Уфимський, К. Торвік-Гарло (баритони), Ангорський, І. Плешаков, В. Полив'яний, Ткаченко. Хор

\footnotetext{
${ }^{38}$ П. Я. «Гейша» С. Джонса. Голос труда. 1922. № 100 (622). 2 августа. С. 4.

${ }^{39}$ По нашим театрам. Голос труда. 1922. № 124 (646). 1 сентября. С. 5.

${ }^{40}$ Внук. «Сильва» - оперетта Кальмана. Голос труда. 1922. № 76 (598). 5 июля. С. 4.

41 Янопольский П. Корневильские колокола. Голос труда. 1922. № 42 (564) 24 мая. С. 4.

42 Леонидов Л. Гримасы НСПа в области искусства. Голос труда. 1922. № 89 (611). 20 июля. С. 3.

${ }^{43}$ Опера ликвидирована. Голос труда. 1922. № 132 (655). 12 сентября. С. 5.
} 
театру налічував 40 чоловік, балет -8 , оркестр - 35. За диригентським пультом стояли О. Срофєєв та М. Медвєдєв, режисуру здійснювали М. Муравйов і Ю. Ткаченко ${ }^{44}$.

Залишивши в поточному репертуарі постановки минулого сезону, Полтавський театр підготував прем'єри опер «Аїда» та «Ріголетто» Дж. Верді, «Сільська честь» П. Масканьї, «Дубровський» Е. Направника, «Піковая дама» та «Мазепа» П. Чайковського, «Борис Годунов» М. Мусоргського. Найбільш вдалою преса визнала постановку «Пікової дами», здійсненої в грудні 1922 року. «Надо отдать справедливость коллектив вышел из своего положения с честью, лучшим доказательством чего служит шумная овация, устроенная в начале последнего акта дирижировавшему оперой А. Г. Ерофееву и режиссеру Н. А. Муравьеву. <..> в целом спектакль следует признать удавшимся: начиная от тонкой шлифовки оркестра, стильных париков, стройного хора и кончая красивыми декорациями - на всем лежал отпечаток положенных больших трудов и продуманности» ${ }^{45}$.

3 приводу постановки опери «Борис Годунов» М. Мусоргського, що вперше була показана в Полтаві в березні 1923 року, преса писала: «Борис Годунов» - опера исключительная: здесь театр обязан дать максимум напряжения, чтобы наряду с музыкальной частью оперы, выявить ее сущность. <..> Основной недостаток постановки отсутствие серьезного критического подхода. Не только отдельные персонажи, но и массовые сцены - народ - все это уж слишком трафаретно и «театрально». Чувствовалась незаконченность, отсутствие отшлифовки каждого в отдельности лица и всей постановки в целом» ${ }^{46}$.

Оцінюючи прем'єру опери Дж. Верді «Аїда», що відбулася у квітні 1924 року, преса відзначила сумлінну постановку, старанну гру симфонічного оркестру, а також прекрасний балет, але знову порушила питання про смаки глядача-непмана ${ }^{47}$. На думку критиків, цей тип глядачів надавав перевагу передусім візуальним і слуховим елементам вистави, тобто ходив «дивитися» і «слухати» оперу. I якщо судити із цього погляду, то, за ствердженням преси, колектив блискуче справився зі своїм завданням: постановка опери, декорації, написані спеціально робітником-самоучкою, талановитим художником Михайлом Гвоздіковим були блискучі ${ }^{48}$.

У лютому 1923 року для виступів у виставах поточного репертуару полтавського колективу запросили одразу трьох прем'єрів Одеської опери: Н. Бартош-Седенко (сопрано), М. Зложинского (тенор) і Г. Генарі (баритон). За їх участі була поновлена опера «Сільська честь»

\footnotetext{
${ }_{44}^{44}$ Открытие зимнего сезона оперы. Голос труда. 1922. № 181 (703). 9 ноября. С. 4.

${ }^{45}$ П. Я. «Пиковая дама» Чайковского. Голос труда. 1922. № 221 (742). 26 декабря. С. 6.

${ }^{46}$ П. Я. «Борис Годунов» Мусоргского. Голос труда. 1923. № 66 (813). 25 марта. С. 5.

${ }^{47}$ Модерато. Опера «Аида». Голос труда. 1923. № 74 (821). 4 апреля. С. 4.

48 Там само.
} 
П. Масканьї, яка традиційно виконувалася в один вечір із «Паяцами» Р. Леонкавалло.

Нові постановки вимагали великої й кропіткої роботи з хором, з якою прекрасно справлявся хормейстер театру О. Свєшников. Під його керівництвом оперний хор, окрім поточного оперного репертуару, підготував ще й концертну програму, де виконав усі 12 частин «Реквієму» В.А. Моцарта. Як солісти виступили Ф. Образцовська (сопрано), О. Ропська (мецо-сопрано), І. Лопатін (тенор) і В. Полив'яний (бас). У рецензії на концерт писалося: «Много труда было вложено в благодарную, но ответственную задачу: познакомить Полтаву с гениальным трудом Моцарта; и надо сказать, что под умелым руководством Свешникова хор, в общем преодолел исключительные трудности произведения, особенно женский, лучше подготовленный и более сильный голосами» ${ }^{49}$. Серед солістів найбільше виділялася О. Ропська, яка, на думку критики, «увлекла свежестью голоса, добросовестной разработкой партии и незамечавшейся доселе в ее оперной работе - классической простотой передачи» ${ }^{50}$.

Кінець сезону 1922-1923 років був затьмарений неприємною подією: після однієї з вистав «Аїди» Дж. Верді в міському театрі трапилася пожежа, яка значно пошкодила театральне приміщення. Щоб завершити сезон, оперний колектив змушений був перейти працювати на сцену Полтавського музичного технікуму, яка була не зовсім пристосована для здійснення оперних постановок. Проте навіть ці незручності й велика плинність у складі солістів не завадили оперному колективу в новому сезоні 1923-1924 років утримати в репертуарі оперні постановки минулих сезонів. Цьому сприяли в насамперед нові солісти: Б. Ісаков (ліричний тенор), Р. Смельянов (драматичний тенор), Б. Альбицька, Ф. Хоржевська (драматичне сопрано), К. Демідова (ліричне сопрано), Завалов (баритон). Повернулася до Полтави і їі колишня фундаторка В. Старостинецька, яка вже в одній із перших вистав за їі участі («Аїді» Дж. Верді) показала себе як «кращий кадр оперного колективу»" Режисеру здійснювали Е. Юнгвальд-Хількевич та С. Коробов, хормейстером працювала Н. Іванова.

У 1923 році державною владою в Україні була проголошена так звана політка «українізації», що спричинила активне впровадження української мови в діловодстві, освіті, пресі й театрі. Однак столичні оперні театри, на відміну від драматичних, не поспішали включати до свого репертуару національну класику, а відбулися лише постановками російських опер на український сюжет і європейською класикою в українському перекладі. Не став винятком у цьому стосунку й Полтавський оперний колектив.

\footnotetext{
${ }^{49}$ Г. Ш. «Реквием» Моцарта. Голос труда. 1923. № 107 (854). 15 мая. С. 3.

${ }^{50}$ Там само.

${ }^{51}$ Г. Ш. Опера. (В музтехникуме). Голос труда. 1923. № 253 (994). 6 ноября. С. 4.
} 
У грудні 1923 року полтавській публіці була знову представлена опера «Галька» С. Монюшка в українському перекладі, а на початку березня 1924 року - прем’єра опери П. Чайковського «Мазепа». Головну партію в останній співав запрошений соліст із Київського оперного театру К. Суслов. Оцінюючи нову постановку преса писала, що «оперный коллектив лишний раз «блеснул» своею слабостью, немощью». «Мазепа (Суслов) - единственная фигура, выделяющаяся на фоне общего «безголосья». Суслов, безусловно, способный актер, обладающий хорошими голосовыми данными. Только его и могла слушать без раздражения музыкальная публика. Досадно только, что этот актер в трупе и «швец и жнец и в дуду игрец» - ему без разбору поручаются всякие партии, как Мазепы, например. Конечно, получился хорошо поющий Суслов, но не было Мазепы» ${ }^{52}$.

У грудні 1924 року під час гастролей у Полтаві корифея української сцени Панаса Саксаганського за участі солістів опери було виконано «Запорожець за Дунаєм» С. Гулака-Артемовського. Однак ця вистава показала, що більшість солістів трупи не мала відповідної підготовки для виконання іï на високому рівні. Преса доброзичливо оцінила виступ гастролера, але розкритикувала більшість виконавців: «Заигранная всеми, кому только не лень, фигура добродушного пьяницы - запорожца, рубахи - сечевика, ожила в мастерских руках, заиграла всеми тонами искрящегося юмора и сочных бытовых мазков. Но уходит со сцены Карась - и с ним исчезает очарование» ${ }^{53}$. Рецензент зазначив, що зі своїми ролями впоралися лише колишні артисти української драматичної трупи М. Костюченко й І. Козловський. Стосовно інших виконавців, писалося: «... артист Суслов так изобразил султана, что удивительно, как это подданные не низложили его и не изгнали со сцены за немилосердное коверканье украинского языка, незнание роли и на редкость плоскую игру. У артистки Фишер Оксана столько же напоминала украинку, сколько тибетского Далай-ламу. Это была вольная прогулка с пением «знатной иностранки» среди чуждых ей «туземцев» ${ }^{54}$.

Завершили сезон дві прем'єрні постановки опер «Жидовка» В. Галеві й «Тоска» Дж. Пучіні. Головні партії в них виконували В. Старостинецька та новозапрошені солісти Одеської опери М. Бартош-Седенко й М. Зложинський, а також місцеві солісти В. Полив'яний (Кардинал у «Жидовці») та К. Торвік-Гарло (Скарпіа в «Тосці»). Режисеру здійснював С. Коробов. Усі прем'єрні постановки пройшли на відремонтованій сцені Театру міськради, де оперний колектив почав працювати вже із січня 1924 року.

\footnotetext{
52 Люмпен. «Мазепа» Чайковского. Голос труда 1924. № 51 (1095). 1 марта. С. 4.

53 Г. Ш. Гастроли Саксаганского. «Запорожец за Дунаем». Голос труда. 1923. № 292 (1033). 22 декабря. С. 3.

54 Там само.
} 


\section{5. Заключний етап діяльності Полтавського оперного театру (сезони 1924-1926 років)}

На початок нового сезону 1924-1925 років у трупі Полтавського оперного колективу залишилися лише оркестр, хор, балет і частина співаків - виконавців другорядних партій ${ }^{5}$. Вихід із цієї несприятливої ситуації знайшов О. Срофєєв. Скориставшись своїми гарними взаєминами з головним режисером Харківської опери М. Боголюбовим, він домовився з ним про виконання солістами столичної опери головних партій у постановках полтавського колективу. Вистави мали відбуватися щотижня по понеділках, після чого співаки мали тієї ж ночі повертатися на роботу в Харків. «Дякуючи цим досить важким, правда, мандрівкам, писала полтавська преса, - наша опера має чудовий склад перших виконавців, які раніше для неї були недосяжними». ${ }^{56}$. Режисер М. Боголюбов, у свою чергу, згадував: «Я, будучи главным режиссером Харьковской оперы, помогал Ерофееву тем, что посылал ему для участия в этих спектаклях свободных артистов, которых Ерофеев хорошо оплачивал и комфортабельно устраивал в своей Полтаве. Наши артисты очень любил гастролировать у гостеприимного директора полтавской школы» ${ }^{57}$. У виставах були задіяні кращі сили столичної Харківської опери: М. Литвиненко-Вольгемут, М. Баратова, О. Добровольська, О. Уляницька (сопрано), Ф. Мухтарова, Г. Лукашевич (мецо-сопрано), О. Каратов, В. Войтенко (тенори), В. Любченко, Д. Бозенсон (баритони), К. Книжников, М. Рейзен, М. Нікольський (баси). Режисуру здійснював А. Кононович, хором керувала Н. Іванова. 3 листопада 1924 року до кінця березня 1925 року щопонеділка за участю столичних співаків відбувалися вистави: «Севільський цирульник» Дж. Россіні, «Фауст» Ш. Гуно, «Аїда», «Ріголетто» i «Травіата» Дж. Верді, «Кармен» Ж. Бізе, «Паяци» П. Масканьї, «Жидовка» Ф. Галеві, «Русалка» О. Даргомижського, Демон А. Рубінштейна, «Свгеній Онєгін», «Пікова дама» та «Мазепа» П. Чайковського, «Борис Годунов» М. Мусоргського. Завершився цей своєрідний сезон 30 березня 1925 року найкращою постановкою сезону оперою «Жидівка» Ф. Галеві 3 М. Литвиненко-Вольгемут у головній партії ${ }^{2}$.

Залучення солістів Харківського оперного театру до виконання головних партій у виставах полтавського колективу, безумовно, виховувало в місцевого глядача високі стандарти музично-художнього сприйняття, однак не вирішувало питання неукомплектованості місцевої трупи. Тому в серпні 1925 року в Полтаві знову постало питання про

\footnotetext{
${ }^{55}$ Г. Ш. Опера в Полтаві. «Аїда», опера Верді. Більшовик Полтавщини. 1924. № 14.20 листопада. C. 3

${ }^{56}$ Там само

57 Боголюбов Н.Н. Шестьдесят лет в оперном театре: воспоминания режиссера. Москва: Издательство ВТО, 1967. С. 262.

${ }^{58}$ Г. Ш. Опера. «Жидовка» Галеві. Більшовик Полтавщини. 1925. Ч. 10 (57). 14 січня. С. 4. 
організацію стаціонарної оперної трупи. Для гарантованої наповненості залу планувалося впровадження абонементної системи. 3 нового репертуару планувалися постановки опер «Лакме» Л. Деліба, «Казки Гофмана» Ж. Оффенбаха, «Вертер» Ж. Массне, «Самсон і Даліла» К. Сен-Санса ${ }^{59}$. Однак восени 1925 року оперна трупа так і не почала своєї роботи. Причиною цього стала конкуренція між Українською музичною драмою ім. Т.Г. Шевченка й оперним колективом, що не могли розділити між собою сцену Міського театру, фінансову допомогу від держави й увагу публіки. На сторінках полтавської преси із цього приводу розгорнулася ціла дискусія. Автор статті «Утворювати оперу гнилизну підтримувати» Сергій Жекін стверджував, що міський театр потрібно віддати для вистав «Шевченківцям» як театру сучасному, що став одним із осередків пролетарської культури, на відміну від оперного театру. «В існуючих операх, - писав він, - можна знайти висвітлення лише поміщицького побуту та гнилих кіл, зовсім сторонніх робітничій масі» ${ }^{60}$. А отже, «утворення в Полтаві опери - $е$ лише піддержка гнилого, що не вмерло й не переродилось на 8-й рік революції. <..> Тільки в далекому майбутньому опера, може, матиме сценічноархеологічну цінність. Тепер-же вся маса свідомих трудящих в один голос каже - «Немає в нашій робітничій кишені грошей на цю дійсно мертву справу. Пошукайте в сторонній!» ${ }^{61}$ У відповідь на цю статтю вийшла інша, автор якої заховався під псевдонімом Сторонній: «Минули ті часи, коли й Пушкіна, Тургенєва, Толстого радили викинути геть, як письменників буржуазних! ...А коли послухати т. Жекіна, то треба зачинити опери в Києві, Харкові, Москві, Одесі і т.д. Все-ж це «піддержка того гнилого, що вмерло» ${ }^{62}$. Виступаючи від імені Політосвіти щодо доцільності організації в Полтаві нової оперної трупи, О. Шраменко в статті-відповіді писав: «Через якийсь час опера вичерпає свій обмежений, відомий та досить «пережований» в Полтаві репертуар, бо Полтава - не Москва, не Харків і не Одеса 3 їх багатьма «комплектами» слухачів та глядачів, що має можливість ставити одну оперу по декілька раз на тиждень або на місяць. <...> Опері треба «не омолодитися» а «переродитися» по змісту, щоб вона стала корисною широким працюючим масам. Про утворення такої опери в м. Полтаві не можна навіть мріяти ${ }^{63}$.

\footnotetext{
${ }^{59}$ Опера в Полтаві. Більшовик Полтавщиини. 1925. Ч. 196 (243). 29 серпня. С. 4.

60 Жекін С. Утворювати оперу - гнилизну підтримувати. Більщовик Полтавщини. 1925. Ч. 235 (282). 14 жовтня. С. 3.

61 Жекін С. Утворювати оперу - гнилизну підтримувати. Більщовик Полтавщчини. 1925. Ч. 235 (282). 14 жовтня. С. 3.

62 Сторонній. Менше запалу, більше спокою. Більщовик Полтавщчини. 1925. Ч. 235 (282). 14 жовтня. С. 3.

63 Шраменко О. Політосвіта має свою думку. (Відповідь на замітки про оперу). Більшовик Полтавщини. 1925. Ч. 240 (287). 20 жовтня. С. 2.
} 
У лютому 1926 року в Полтаві все таки була здійснена остання спроба організації оперної трупи. До складу колективу були запрошені солісти: П. Карпова， В. Старостинецька， О. Холодна (сопрано); Г. Лукашевич, В. Товстолужська (мецо-сопрано); О. Нікітін, Р. Смельянов, Данченко й C. Нікітенко (тенори); Г. Генари, Михайлов, Панков (баритони); Случановський, В. Полив'яний та Алмазов (баси). Диригенти О. Єрофєєв та М. Шейн ${ }^{64}$. До складу колективу ввійшов хор у 35 чоловік та оркестр із 25 чоловік. Новий колектив продовжив репертуарну лінію минулих оперних сезонів, що складалася 3 популярних опер: «Севильский цирульник» Дж. Россіні, «Фауст» Г. Гуно, «Аїда», «Риголетто», «Травіата» Дж. Верді, «Тоска» Дж. Пучіні, «Жидовка» Ф. Галеві, «Кармен», Ж. Бізе, «Паяци» Р. Леонкавалло, «Борис Годунов» М. Мусоргського, Євгеній Онєгін» та «Пікова дама» П. Чайковського. Окрім того, під орудою нового диригента М. Штейна були представлені ще три прем’єрні постановки: «Самсон і Даліла» К. Сен-Санса, «Лакме» Л. Деліба та «Князь Ігор» О. Бородіна. Вистави йшли дуже щільно, майже щодня 3 невеликими перервами. На жаль, незважаючи на широкий репертуар і професійний рівень виконання, оперний сезон закінчився значно раніше, ніж це передбачалося. Однією з причин стало «недостатнє розповсюдження абонементів у квітні й через те скрутне матеріальне становище численної оперової трупи ${ }^{65}$. «Другого разу соліст, що ввечері співає, в день карбованця на сніданок не може дістати, - писалося в місцевій пресі. - Так і розливається голодним соловейком. Про хористів і говорити нічого. Хронічно голодують» ${ }^{66}$. Останньою виставою оперного колективу стала опера Ж. Бізе «Кармен» з В. Товстолужською та С. Нікітенко-Віманом у головних партіях.

У другій половині 20 -х років XX ст. держава перейшла на новий етап економічного розвитку - індустріалізацію. У цей час влада починає безцеремонно втручатися в культурні процеси країни. Відбувається активне одержавлення столичних оперних театрів і перехід їх у повну залежність від фінансування мистецьких владних структур. Однак зміцнення театральних колективів у великих містах здійснювалося за рахунок притягнення кращих музичних сил із периферії, що значно ослаблювало, а часом просто руйнувало іiі музичну культуру. Так, у 1928 році постановою НКО від 12 червня Полтавський музичний технікум був переведений до Харкова і злитий з музично-драматичним інститутом $^{67}$. У зв'язку з цим Полтаву залишили викладачі музичного технікуму, що становили основний склад Полтавського симфонічного оркестру та перейшли на роботу в оркестр Харківської опери.

\footnotetext{
${ }^{64}$ Відкриття опери. Сьогодні опера починає свій сезон. Робітник. 1926. № 50 (99). 3 березня. С. 4

65 Останні оперові вистави. Робітник. 1926. № 75 (124) 10 квітня. С. 3.

${ }^{66}$ Шиляновський Г. Закриття опери. Робітник. 1926. № 84 (133). 14 квітня. С. 3.

${ }^{67}$ Шевченко С.А. Олександр Гаврилович Ерофєєв. ДАПО. Ф. 8811. Оп. 1. Спр. 5. Арк. 14.
} 
Залишившись без основних музично-театральних сил, припинив свою діяльність і Полтавський оперний театр.

\section{ВИСНОВКИ}

Зважаючи на віддаленість Полтави від великих музично-театральних центрів, діяльність у місті оперного колективу, який без постійної державної фінансової підтримки зміг протриматися майже 5 років, $\epsilon$ унікальним явищем. Діяльність Полтавського оперного колективу розпочалася з декількох спроб його організації, впродовж трьох сезонів мала більш-менш стабільний характер роботи й закінчилася виставами «по понеділках» та останньою спробою організації стаціонарного оперного колективу. Відповідно до цього, можна виділити три періоди його функціонування: організаційний, стабільний і заключний.

На відміну від столичних оперних колективів, Полтавський оперний колектив не відзначився експериментальними постановками опер чи цікавими режисерськими рішеннями. 3 преси дізнаємося, що в загальних досягненнях він стояв ще «на линии старой оперы, с явным преобладанием певца над актером и постановщиком. Во главе здесь вокально-музыкальная часть; на ней видно фиксированы стремления руководителей. И надо отдать справедливость - поставлена она на достаточную высоту в целом. Касаясь игры, не приходится говорить об оригинальной, своей трактовке оперных образов. Больше всего исполнители боятся уйти от общепринятых «исконных» шаблонов и дать, упаси боже, что-нибудь новое. Традиционное же дается неплохо, в худшем случае старательно» ${ }^{68}$. Щоб зацікавити полтавську публіку, керівництво Полтавського оперного колективу працювало над розширенням репертуару, уважно слідкуючи за новими постановками інших оперних театрів i, по можливості, включаючи їх у свій репертуар.

Фінансова нестабільність не давала змоги утримати в Полтаві яскравих особистостей, які стояли біля витоків полтавського оперного колективу. Ненадовго втримувалися в трупі театру й молоді співаки, що розпочали свій шлях у Полтаві. «Надо сказать, что работа в те годы в Полтавской опере была не очень заманчивой, - згадував колишній іiі соліст I. Козловський, - театр существовал «на выручку», труппа была бедная, заработная плата актеров низкая. Выручка кассы делилась среди работников театра по «марочной системе» с учетом занятости актеров и их «положения» ${ }^{69}$. Тому не дивно, що, здобувши неоціненний досвід роботи в колективі та збагативши свій оперний репертуар, молоді співаки переходили працювати на більш престижні, переважно столичні оперні сцени.

\footnotetext{
${ }^{68}$ Г. Ш. Опера. (В музтехникуме). Голос труда. 1923. № 253 (994). 6 ноября. С. 4.

69 Музыка - радость и боль моя: Статьи, интервью, воспоминания / сост. И. Сафронова, Н. Слезина. Москва : Издательское объединение «Композитор», 1992. С. 309.
} 
Однак, незважаючи на величезну плинність художнього складу, завдяки зусиллям художнього керівництва Полтавського оперного театру на чолі 3 талановитим диригентом О. Срофєєвим полтавська публіка отримала можливість ознайомитися з великим і різноманітним репертуаром. Здійснено постановки двадцяти трьох опер і трьох оперет, серед яких були й шедеври оперної класики - «Аїда» Дж. Верді, «Пікова дама» П. Чайковського та «Борис Годунов» М. Мусоргського. Завдяки залученню до участі у виставах гастролерів, полтавці мали змогу почути не лише місцевих виконавців, а й таких видатних співаків, як П. Цесевич, М. Бочаров, Г. Пирогов, М. Рейзен, М. ЛитвиненкоВольгемут та ін. Важливим також $\epsilon$ той факт, що в самому Полтавському оперному колективі працювали й починали свій шлях такі митці, як І. Козловський, О. Свєшников, О. Срофєєв, І. Гітгарц, О. Ропська, Р. Фішер, котрі пізніше зробили визначний внесок не лише в розвиток культури України, а й інших республік колишнього Радянського Союзу.

\section{АНОТАЦІЯ}

У статті йдеться про унікальне явище для української музичної культури - Полтавський оперний театр, що діяв в Україні в 20-х роках $\mathrm{XX}$ ст. Зосереджено увагу на творчому шляху окремих особистостей, які стояли біля витоків цього мистецького колективу або творчо зростали в ньому: диригентів О. Єрофєєва, І. Гітгарця, хормейстера О. Свєшникова, співаків І. Козловського, І. Плешакова, О. Ропської, Р. Фішер. Усі вони зробили вагомий внесок в культуру не лише України, а й інших республік колишнього Радянського Союзу. Завдяки діяльності Полтавського оперного театру місцева публіка отримала можливість ознайомитися з великим і різноманітним репертуаром. За час існування колективу здійснено постановки двадцяти трьох опер і трьох оперет, серед яких були й найвищі досягнення оперної класики: «Аїда» Дж. Верді, «Пікова дама» П. Чайковського, «Борис Годунов» М. Мусоргського.

На основі зібраної інформації, що складається з афіш, повідомлень, оглядових і критичних статей, надрукованих у регіональних газетах, архівних матеріалів, спогадів очевидців і безпосередніх учасників тих подій, у статті здійснена спроба більш повного розкриття діяльності Полтавського оперного театру, проаналізовано його репертуарну лінію та виділено етапи його роботи.

Донедавна увага мистецтвознавців і театрознавців зосереджувалася на вивченні музичної культури переважно великих культурних мистецьких осередків, таких як Київ, Харків, Одеса та Львів. Сьогодні ситуація починає змінюватися й увагу дослідників все більше привертає музична 
культура регіонів, не менш важлива та цікава. Одним із яскравих музичних культурних осередків 20 -х років XX століття є Полтавщина. Відомий співак I. Козловський, що на той час перебував у місті, згадує: «Театральная жизнь Полтавы в 20-х годах была чрезвычайно интересной и богатой. Она развивалась с той стремительностью, которая свойственна периодам великих общественных преобразований.<..>. В Полтаве возникло пять театров, все они существовали без дотаций государства». $<\ldots>^{70}$. Серед цих колективів почесне місце посідає Полтавський оперний театр як найвище досягнення музичної культури Полтави того часу.

3 Полтавським оперним театром пов'язано становлення і творче зростання відомих митців, що зробили вагомий внесок в культуру не лише України, а інших республік колишнього Радянського Союзу. Це диригенти - заслужений артист УРСР, заслужений діяч мистецтв РРФСР О. Єрофєєв, заслужений діяч мистецтв БРСР І. Гітгарц; хормейстер народний артист СРСР О. Свєшников; співаки - народний артист СРСР I. Козловський, заслужений діяч мистецтв РРФСР І. Плешаков, народна артистка УРСР О. Ропська. На сцені цього театру 3 гастролями виступали такі видатні співаки, як П. Цесевич, Г. Пирогов, М. Бочаров, солісти Харківського оперного театру: М. Литвиненко-Вольгемут, Ф. Мухтарова, П. Карпова, В. Любченко, М. Рейзен і багато інших.

Інформація про діяльність Полтавського оперного театру міститься в статтях А. Литвиненко, М. Фісуна, В. Шевченка, К. Гладиша, Д. Козачківського, в енциклопедичному довіднику «Полтавщина» А. Кудрицького; у краєзнавчих роботах В. Волоскова, О. Чепіль, Є. Кобиляшної, В. Тесленка; згадується в монографіях про музичнотеатральне життя України Ю. Станішевського, О. Ізваріної, у дипломній роботі К. Данилової. Проте не існує жодного системного та вичерпного дослідження про діяльність цього унікального в регіоні творчого колективу.

Мета статті - відновити й більш повно розкрити діяльність Полтавського оперного театру 20-х pp. XX ст., проаналізувати його репертуарну лінію та виділити етапи роботи; зосередити увагу на творчому шляху окремих особистостей, які стояли біля витоків цього мистецького колективу або творчо зростали в ньому.

Джерелознавчу базу дослідження становлять матеріали Полтавського державного обласного архіву та музею «Музична Полтавщина», що знаходиться в Полтавському музичному коледжі; повідомлення, оглядові та критичні статті, надруковані в регіональних газетах: «Известия» 1919 року, «Радянська влада» 1920 року, «Вісти» (Известия) 1920, 1921, 1922 років, «Голос труда» 1922, 1923, 1924 років,

\footnotetext{
${ }^{70}$ Козловский И. «Пение - высокий университет». Смена. 1979. № 10. С. 25.
} 
«Більшовик Полтавщини» 1924, 1925 років, «Робітник» 1926 року; спогади очевидиці тих подій О. Чернової, режисера М. Боголюбова, автобіографії О. Срофєєва, І. Козловського та О. Ропської, відомості $з$ енциклопедій.

\section{ЛІТЕРАТУРА}

1. Алеко. «Вертер». Вісти (Известия). 1921. № 96 (271). 13 мая.

2. Алеко. «Евгений Онегин». Вісти (Известия). 1921. № 107 (282). 26 мая.

3. Алеко. «Евгений Онегин». Вісти (Известия). 1921. № 83 (258). 23 апреля.

4. Алеко. «Паяцы» Леонкавалло. Вісти (Известия). 1921. № 275 (445). 16 декабря.

5. Алеко. 3-й симфонический концерт. Вісти (Известия). 1921. № 14 (189). 22 января.

6. Алеко. Гастроль Цесевича и Карасуловой. Вісти (Известия). 1922. № 65 (515). 23 марта.

7. Алеко. Оперные спектакли. Вісти (Известия). 1920. № 146. 26 ноября.

8. Алеко. Оперный вечер. Вісти (Известия). 1920. № 119. 24 октября.

9. Афіша опери «Запорожець за Дунаєм» С. Гулака-Артемовського. Музей «Музична Полтавщина» Полтавського музичного коледжу імені М.В. Лисенка. Інв. № 169.

10. Башкирская энциклопедия. / гл. ред. М.А. Ильгамов. Уфа, 2011. T. $7.663 \mathrm{c}$.

11. Боголюбов Н.Н. Шестьдесят лет в оперном театре: воспоминания режиссера. Москва : Издательство ВТО, 1967. 302 с.

12. Большой вокальный концерт. Вісти (Известия). 1921. № 253 (423). 20 ноября.

13. В театрах. Вісти (Известия). 1921. № 152 (322). 22 июля.

14. Відкриття опери. Сьогодні опера починає свій сезон. Робітник. 1926 р. № 50 (99). 3 березня.

15. Внук «Полярная звезда». Открытие сезона. Голос труда. 1922. № 80 (602). 9 июля.

16. Внук. «Сильва» оперетта Кальмана. Голос труда. 1922. № 76 (598). 5 июля.

17. Г. Ш. «Евгений Онегин. Голос труда. 1923. № 285 (1026). 14 декабря.

18. Г. Ш. «Реквием» Моцарта. Голос труда. 1923. № 107 (854). 15 мая.

19. Г. Ш. Гастроли Саксаганского. «Запорожец за Дунаем». Голос труда. 1923. № 292 (1033). 22 декабря. 
20. Г. Ш. Гастроли Цесевича. «Борис Годунов» Мусоргского. Голос труда 1924. № 29 (1073). 5 февраля.

21. Г. Ш. Концерт Пирогова. Робітник. 1926. № 5 (54) 8 січня.

22. Г. Ш. Опера в Полтаві. «Аїда», опера Верді. Більшовик Полтавщини. 1924. № 14. 20 листопада.

23. Г. Ш. Опера. (В музтехникуме). Голос труда. 1923. № 253 (994). 6 ноября.

24. Г. Ш. Опера. «Жидовка» Галеві. Більшовик Полтавщини. 1925. Ч. 10 (57). 14 січня.

25. Г. Ш. Открытие оперных гастролей. Голос труда. 1924. № 110 (1154) 15 мая.

26. Г. Шиляновський Закриття опери. Робітник. 1926. № 84 (133). 14 квітня.

27. Для Української Опери. Радянська влада. 1920. . 58 (73). 10 березня.

28. Довідка В. Старостинецькій. Музей «Музична Полтавщина» Полтавського музичного технікуму імені М.В. Лисенка. Інв. № 5/3.

29. Донцов В.П. А голос так дивно звучал. Киев : Альфа Реклама, 2010. $364 \mathrm{c}$.

30. Срофєєв О. Автобіографія. Музей «Музична Полтавщина» Полтавського музичного коледжу імені М.В. Лисенка. Інв. № 7/4.

31. Срофєєв О. Лист до К. Данилової від 19.03.1963. Музей «Музична Полтавщина» Полтавського музичного коледжу імені М.В. Лисенка. Інв. № 333/21.

32. Известия. 1919. № 68 (84). 11 мая.

33. Козловський И. «Пение - высокий университет». Смена. 1979. № 10. C. 24-26.

34. Леонидов Л. Гримасы НЕПа в области искусства. Голос труда. 1922. № 89 (611). 20 июля.

35. Люмпен. «Мазепа» Чайковского. Голос труда. 1924. № 51 (1095). 1 марта.

36. Модерато. Опера «Аида». Голос труда. 1923. № 74 (821). 4 апреля.

37. Музыка - радость и боль моя: Статьи, интервью, воспоминания / сост. И. Сафронова, Н. Слезина. Москва : Композитор, 1992. 384 с.

38. Опера в Полтаві. Більшовик Полтавщини. 1925. Ч. 196 (243). 29 серпня.

39. Опера ликвидирована. Голос труда. 1922. № 132 (655). 12 сентября.

40. Оперная труппа. Вісти (Известия). 1920. № 92.19 сентября.

41. Оперные гастроли. Голос труда. 1924. № 102 (1146). 6 мая.

42. Останні оперові вистави. Робітник. 1926. № 75 (124) 10 квітня.

43. Открытие зимнего сезона оперы. Голос труда. 1922. № 181 (703). 9 ноября. 
44. П. Я. «Борис Годунов» Мусоргского. Голос труда. 1923. № 66 (813). 25 марта.

45. П. Я. «Гейша» С. Джонса. Голос труда. 1922. № 100 (622). 2 августа. C. 4.

46. П. Я. «Пиковая дама» Чайковского. Голос труда. 1922. № 221 (742). 26 декабря.

47. Передача театров в руки коллективов. Вісти (Известия). 1921. № 274 (444). 15 декабря.

48. По нашим театрам. Голос труда. 1922. № 124 (646). 1 сентября.

49. Репертуар 1-го Советского театра. Вісти (Известия). 1921 г. № 154 (324). 24 июля.

50. Жекін С. Утворювати оперу - гнилизну підтримувати. Більшовик Полтавщзини. 1925. Ч. 235 (282). 14 жовтня.

51. Сторонній. Менше запалу, більше спокою. Більшовик Полтавщини. 1925. Ч. 235 (282). 14 жовтня.

52. Студия при оперном хоре. Вісти (Известия). 1921. № 29 (204). 11 февраля.

53. Украинская опера Музкома. Радянська влада. 1920. Ч. 53 (68). 4 березня.

54. Чєрнова О. Полтавська опера 1920-1925 років. (Спогади очевидця). Лисенко І. Музична культура України у спогадах, матеріалах, листах. Київ : Рада, 2008. С. 106-112.

55. Шевченко С.А. Олександр Гаврилович Ерофєєв. ДАПО. (Державний архів Полтавської області). Ф. 8811. Оп. 1. Спр. 5.

56. Шраменко О. Політосвіта має свою думку. (Відповідь на замітки про оперу). Більшовик Полтавщини. 1925. Ч. 240 (287). 20 жовтня.

57. Янопольский Г. Корневильские колокола. Голос труда. 1922. № 42 (564) 24 мая.

Information about authors: Andrieieva V. I., Acting Associate Professor at the Department of Opera Singing Ukrainian National Tchaikovsky Academy of Music 1-3/11, Horodetskogo str., Kyiv, 01001, Ukraine 